\title{
THE ROLE OF PENALTIES IN CRIMINAL LAW
}

\author{
LEON A. TULIN
}

Around the concept "criminal intent," as used in the criminal law, some of the most intensive battles of legalistic dialectics have been waged." Sometimes the term connotes "purposive" human activity ; ${ }^{2}$ at other times, it connotes the idea of "anticipation," not necessarily "desire." ${ }^{3}$ Again it is said that something other than subjective anticipation comes within the ample bosom of "intent." Even though it may be demonstrated beyond the slightest possibility of doubt that the particular individual whose "mind" is being probed by the mental fluoroscope of court and jury did not anticipate the consequences for which society is now seeking to charge him, he will nevertheless be held to have "intended" them if a reasonable person in his position would have anticipated them. In other words, the courts and juries are supposed to project themselves, being reasonable men, into the position of the defendant and then determine whether they would have anticipated the consequences that did in fact occur. ${ }^{4}$

1 Smith, Crucial Issues in Labor Litigation (1907) 20 HARV. L. Rev. 253, 256 et seq.; Beale, Criminal Attempts (1903) 16 HArv. L. Rev, 491; Cook, Act, Intention and Motive in the Criminal Law (1917) 26 Yald LAW JourNAL 645 .

2 "Intention, then, is the attitude of mind in which the door of an act adverts to a consequence of the act and desires it to follow. But the doer of an act may advert to a consequence and yet not desire it; and therefore not intend it." MARKBY, ELEMENTS OF LAW (6th ed. 1905) 119.

3 "But when you shoot at Styles, I am talking with him and am standing close by him. And from the position in which I stand with regard to the person you aim at, you think it not unlikely that you may kill me in your attempt to kill him. Now you intend my death without desiring it." 1 AUSTIN, JURISPRUDENCE (5th ed. 1885) 424.

4 Utter discord is thus achieved between the viewpoint of the psychologist, psychiatrist, and criminologist who assert that society must focus on the individual, and the theory of the law. Beccaria in the 18th Century contended that the existing barbarous methods of capricious punishment should be abolished in favor of a standarized code of penalties. BECCArta, Crimes and PUnishments (5th ed. 1801). His theory rested on the assumption that each man was possessed of a free will so that a given course of conduct was the result of an untramelled choice. Consequently, the causative factors of human conduct always being the same, difforentiation in punishments should be based on the acts so that the pain inflicted would outweigh the pleasure attained by the act. Entrenched on our throne of detached sophistication we wonder at and rather enjoy thr naivete of the theory. But the doctrine that a man intends the natural and probable consequences of his acts is merely another manifestation of that theory. It starts with the inarticulate assumption that, except in cases of marked abnormality easily recognizable by a layman, one individ- 
Still, it is this concept "intent" which is said to constitute the foundation of our criminal law structure. By means of determining "its" meaning decisions are purported to be made. But the cases suggest that the foundation is in a disintegrated state.

In a recent Georgia case "the defendant and some other gentlemen appeared at the home of a negro and one of them announced that he could have until that night to leave. The defendant then said, "I will not give him that long," and immediately struck him on the head with a heavy weapon. The defendant was charged with assault with intent to kill and was convicted. He appealed on the ground that the trial court committed error in refusing to charge the jury on simple assault and battery. The conviction was reversed, the court saying:

"Under the facts in this case, would it not be just as reasonable for the jury to conclude that for some undisclosed reason the defendant desired to frighten the prosecutor away from his home, and that the stick was used as a persuasive argument that he had best not wait until that night to leave. .... I I seems to us that one of the conclusions the jury would be authorized to reach from the evidence was that the defendant did not intend to kill the prosecutor; and, this being true, they should have been given the opportunity to find him guilty of assault and battery." :

A subsequent Georgia case ${ }^{7}$ affords an interesting comparison. There, the defendant, a negro, while driving at a reckless rate of speed, struck a car in which the prosecutrix, a white woman, was riding, thus causing her very severe injuries. There was evidence that he was drunk at the time. A conviction for "assault with intent to murder" was upheld. The opinion does not mention specific intent. ${ }^{8}$

In the acquisitive crimes the classical distinction between larceny by trick and obtaining money or property by false pretenses rests on the intent of the prosecuting witness. If he

ual is just like another; and concludes that if twelve jurymen would have anticipated certain consequences, the defendant must have, no matter what contrary evidence there is.

5 Posey v. State, 22 Ga. App. 97, 95 S. E. 325 (1918).

Ibid. 102, 95 S. E. at 327.

7 Chambliss v. State, 139 S. E. 80 (Ga. 1927).

${ }^{8}$ Cf. Thacker v. Commonwealth, 134 Va. 767, 114 S. E. 504 (1922). There the defendant while returning from a church festival in an intoxicated condition fired at a lamp burning in a tent occupied by the prosecutrix and her two children. The bullet narrowly missed the prosecutrix. A conviction for attempt to murder was reversed. The court said: "When a statute makes an offense to consist of an act combincd with a particular intent, that intent is just as necessary to be proved as the act itself, and must be found as a matter of fact before a conviction can be had; and no intent in law or mere legal presumption, differing from the intent in fact, can be allowed to supply the place of the latter." Ibid. 770, 114 S. E. at 305. 
intended to pass property in the goods or money, the defendant is guilty of obtaining money or property by false pretenses, but if he intended merely to divest himself of possession, the defendant is guilty of larceny by trick. ${ }^{\text {D }}$ Defendants charged with one crime have repeatedly professed their guilt under the other. And sometimes their contentions have been upheld.10 These cases, translated into other terms, even assuming definiteness in the concept "intent" depend on the juries' guess as to whether the prosecuting witness intended one or another of two abstractions which he had never contemplated and which he can never understand. Thus, in a recent case in the New York Court of Appeals, ${ }^{11}$ the defendant falsely represented to the prosecuting witness that a lease that he had on an apartment had two years to run. In fact it had expired. He induced the prosecuting witness to "sublet" the apartment and received one month's rent in advance. The defendant was convicted of larceny but on

9 Bishop, Criminal LaW (9th ed. 1923) § 809; Wharton, Criminal LAW (11th ed. 1912) § 1126.

${ }^{10}$ Hawes v. State, 112 So. 761 (Ala. 1927); Regina v. Williams, 7 Cox C. C. 355 (1857); see Rex v. Nicholson, 2 Leach C. C. 698 (1794); Rex v. Hawtin, 7 Car. \& P. 281 (1836); (1921) 30 Yale LaW Journal 613; (1920) 20 CoL. L. Rev. 318. A similar difficulty exists in the distinctions between embezzlement and larceny. "The force of tradition caused the crime of embezzlement to be regarded as so far distant from larceny that to this day, in some jurisdictions at least, a slip corner is kept open for thieves to contend, if indicted for larceny, that they should have been indicted for embezzlement, and if indicted for embezzlement, that they should have been indicted for larceny and to escape on that ground." Holmes, Colifected Legal Papers (1921) 188. The "slip cornor" was beautifully exemplified in Commonwealth v. O'Malley, 97 Mass. 584 (1867). In that case the defendant was first indicted for larceny, tried and found not guilty by the jury. He was then indicted for embezzlement on the same facts and convicted. An appeal was taken and the conviction was reversed on the ground that the offense was larceny and not embezzlement. The defendant could not be tried again because of the rule of double jeopardy. Compare the attitude of Holmes, J. in Commonwealth v. Ryan, 155 Mass. 523, 30 N. E. 364 (1892). There, an employer, suspecting his employee, the defendant, sent a detective to his own store to make a purchase with marked money. The defendant dropped the money in the cash register without registering it and a moment later took it out again. The defendant was indicted for embezzlement and appealed, claiming that sinco he had taken the money from the cash register, he had taken it from the possession of the master and was therefore guilty of larceny. The conviction was affirmed on the ground that since the money had been deposited in the drawer for the defendant's convenience, possession had not rested in the master. Holmes, J. said at page 530: "The distinction may bo arbitrary, but, as it does not affect the defendant otherwise than by giving him an opportunity, whichever offense he was convicted of, to contend that he should have been convicted of the other, we have the less uneasiness in applying it."

11 People v. Noblett, 244 N. Y. 355, 155 N. E. 670 (1927). Crane, J. dissented with opinion in which Andrews, J. concurred. 
appeal the conviction was quashed on the ground that, just as in earlier New York cases, ${ }^{12}$ there was no evidence to warrant the finding that the prosecuting witness "intended" to pass "possession" only. ${ }^{13}$

Some of the attempt cases offer fine opportunity for mental gymnastics. In some of these cases it was absolutely impossible to commit the physical or property injury "attempted." Thus, in People $v$. Lee Kong, ${ }^{\text {It }}$ the defendant, a keeper of a gambling establishment fired at a hole through which he thought a policeman was watching. The defendant's aim was perfect, the bullet passing through the hole, but fortunately the policeman was

12 People v. Dumax, 106 N. Y. 502, 13 N. E. 325 (1887); see Smith v. People, 53 N. Y. 111 (1873); Shipply v. People, 86 N. Y. 375 (1881); Loomis v. People, 67 N. Y. 322 (1876).

13 Judging from $\$ 1290$ of the N. Y. Penal Code, it would seem that the legislature intended to destroy the difficulties causcd by virtue of the distinctions between larceny, larceny by trick, embezzlement, and obtaining money or property by false pretenses. The statute provides as follows:

"A person who, with the intent to deprive or defraud the true ormer of his property, or of the use and benefit thereof, or to appropriate the same to the use of the taker, or of any other person:

1. Takes from the possession of the true owner, or of any other person; or obtains from such possession by color or aid of fraudulent or false representation or pretense, or of any false token or writing; or secrets, withholds, or appropriates to his own use, or that of any person other than the true owner, any money, personal property, thing in action, evidence of debt or contract, or article of value of any hind; or,

2. Having in his possession, custody, or control, as a bailee, servant, attorney, agent, clerk, trustee, or officer of any person, ascociation, or corporation, or as a public officer, or as a person authorized by agreement, or by competent authority, to hold or take such possession, custody, or control, any money, property, evidence of debt or contract, article of value of any nature, or thing in action or possession, appropriates the same to his own use, or that of any other person other than the true owner or person entitled to the benefit thereof,

Steals such property, and is guilty of larceny."

But the interpretation given to it by the courts in such cases as People v. Dumar, supra note 12 and People v. Noblett, sapra note 11, has practically nullified the legislative attempt to destroy the historical distinctions between the crimes.

Mass. Gen. Laws (1921) c. 266, § 230 provides as follows: "Whoever steals, or with intent to defraud, obtains by a false pretense, or whoever unlawfully and with intent to steal or embezzle, converts or secretes, with intent to convert, the money or personal chattel of another, whether such money or personal chattel is or is not in his possession at the time of such conversion or secreting, shall be guilty of larceny . . . " Ibid. c. 277, \$ 41 provides that an allegation that defendant "stole said property" will be supported by proof of larceny, embezzlement or obtaining property by false pretenses. Ibid. c. $277, \S 40$ allows a defendant to apply for a bill of particulars in such a case. The difficulties existing in New York are thus avoided. See Commonwealth v. Kelley, 1S4 Mrass. 320, 68 N. E. 340 (1903); Commonwealth v. McDonald, 187 Mass. 581, 73 N. E. 852 (1905).

1495 Cal. 666, 30 Pac. 800 (1892). 
watching from another part of the building. The defendant was indicted and found guilty of assault with intent to kill. The case has afforded material for much discussion. One commentator has written as follows: ${ }^{15}$

"If he intended to bring his bullet in contact with a policeman supposed to be behind the hole in the roof, his act if carried to the intended physical contact would have been criminal, and he was accordingly held guilty of an attempt to kill. If, on the other hand, he took the hole with the light shining through it for a human eye, and shot to put his bullet into the supposed eye, since the supposed eye was only a lighted hole, the intended contact was not criminal and he was not guilty of a criminal attempt."

One would like to ask just how a jury can tell whether the defendant intended to bring his bullet in contact with a policeman supposed to be behind the hole in the roof or to puncture an eye which in reality was only a hole.

When confronted with this noose of words fashioned by such terms as "intent", "purpose", "anticipation", "motive", "specific intent", "constructive intent", "transferred intent," etc., one wonders whether or not the maker of the noose is not very often also its victim. Is this careful microsopic process of examining the defendant's "state of mind" anything more than the use of a phantom microscope on an imagined subject? History, of course, explains much of this bizarre methodology. A system of criminal law now conceived would obviously be very different. If stare decisis must be a religion, let us worship as little as possible at the shrine of ex post facto rationalizations. ${ }^{10}$

Criticism of method and nothing more is not very serious. Criticism of unfortunate results, however, which may be begat by method is a different matter. It is submitted that the conceptual and anachronistic method used in the solution of criminal cases very frequently obscures fundamental problems. One enmeshed in a tangle of elusive concepts may think less of where he will be when he finally gets out than of the fact that he must get out. An analysis of the methods used by the courts in determining criminal responsibility for injury caused by reckless driving when the defendant is charged with battery is illuminating.

It is a commonplace that an "intent to inflict" injury must exist in order to convict for assault and battery. Discussion of this requirement arises most frequently where, in a prosecution for assault, the evidence shows that, to the knowledge of the de-

15 Beale, Criminal Attempts (1903) 16 HaRv. L. Rev. 491, 495.

18 "We are well on our way toward a shift from following decisions to following so-called principles, from stare decises to stare dictis." Oliphant, A Return to Stare Decisis (1928) 6 AM. LAW Schoor REv. 215, 216. 
fendant, it was physically impossible for him to inflict injury, although an observer would have believed that danger was imminent. Thus, some courts have held that if the defendant points a gun which he knows to be unloaded at the prosecuting witness, he is not guilty of assault even though the prosecuting witness believed it to be loaded and reacted accordingly. ${ }^{17}$ The reason assigned is that the defendant did not intend to inflict injury. Obviously if the phrase "lack of intent" is used to describe the physical impossibility of inflicting injury by the means employed, it can have no bearing where the defendant is being prosecuted for battery. But the courts in the latter cases also require that the defendant "intend to inflict injury." Here, however, "lack of intent" is used to describe that behavior which an observer would describe as "negligence." In other words, there can be no such thing as a "negligent" battery.13

Let us set up three cases. In the first case $X$ and $Y$ have been on the outs for quite some time. $X$ has sworn on different occasions that some day he will get $Y$. There is testimony to the effect that on the day that the injury occurred, $\mathbb{X}$ told $Z$ that he was going to run into $Y$ with his car and then pretend it was an accident. $X$ while driving at 50 miles an hour, within city limits, and on the wrong side of the road, runs into and severely injures $Y$.

In the second case, $A$ is late for a date with his sweetheart. In order to minimize as much as possible the expected frigid welcome, he drives his car at 50 miles an hour and while taking the inside of a left hand curve, crashes into the prosecuting witness's car and severely injures him.

In the third case, $C$, while driving slightly in excess of the statutory limit strikes and severely injures $D$. There is evidence to the effect that injury would have been avoided if $C$ had driven more slowly.

From previous generalizations in battery cases it would be expected that the defendant would be convicted in the first case, and acquitted in the others on the ground of lack of intent to inflict injury. But a study of the cases reveals that the defen-

17 Chapman v. State, 78 Ala. 436 (1885); State v. Sears, 86 M1o. 169 (1885) ; People v. Sylva, 143 Cal. 62, 76 Pac. $\$ 14$ (1904); State v. Godirey, 17 Or. 300,20 Pac. 625 (1889). Contra: Commonwealth v. White, 110 IIass 407 (1872); State v. Shephard, 10 Iowa 126 (1859); Jiullen v. State, 45 Ala. 43 (1871) (assault with intent to murder). Cf. State v. Barry, 45 Mont. 598, 124 Pac. 774 (1912) (where defendant was acquitted breause prosecuting witness did not see defendant point the gun at him). Some states which profess to require that the gun must be loaded have praetically nullified its effect by placing the burden of proving that the gun was unloaded on defendant. Territory v. Gomez, 14 Ariz. 129, 125 Pac. 702 (1912); State v. Herron, 12 Mont. 230, 29 Pac. 810 (1892).

${ }^{18}$ See for example, State v. Schutte, 87 N. J. L. 15, 93 Atl. 112 (1015); cf. Clarars, Criminat Lat (Mikell, 3d ed. 1915) 267. 
dant is generally held guilty in the first two cases and innocent in the last.

In the first case, obviously, there is no discussion of the presence or absence of "intent." If intent means anything it certainly describes such a fact situation. But in case two it is around the concept "intent" that the battle is waged. Counsel for defendant strenuously contends that a verdict of acquittal must be directed and counsel for the state contends just as strenuously that the defendant did "intend" to inflict the injury. The court holds that since the defendant intended to step on the accelerator, and drive on the wrong side, and since he must be regarded as having "intended" the natural and probable consequences of his acts, he intended to inflict the injury and is therefore guilty of a battery.19

In case three, the prosecution makes the same contention but the court holds that there is no such thing as a negligent battery. Admitting for the moment that there is utility in regarding state of mind as something apart from behavior, the states of mind of the defendant in the last two cases can hardly be distinguished. An introspectionist would probably say that neither defendant "willed" the eventual result. A Watsonian behaviorist would explain both cases in terms of stimulus and response. A layman would say that neither defendant "wanted" to inflict the injury. Obviously, if intent describes "state of mind" both

${ }^{19}$ In the leading case of State v. Schutte, supra note 18, at 18, 93 Atl. at 114, the court said: "The excessive rate of speed at which an automobile is driven is a product of the will of its driver, and not the result of a mere inattention or negligence." See also Brimhall v. State, 255 Pac. 165 (Ariz. 1927) ; Vasques v. State, 259 Pac. 1005 (Cal. 1927) ; People v. Hopper, 69 Colo. 124, 169 Pac. 152 (1917); Tift v. State, 17 Ga. App. 663, 88 S. E. 41 (1916) ; Schneider v. State, 181 Ind. 218, 104 N. E. 69 (1914) distinguishing Luther v. State, 177 Ind. 619,98 N. E. 640 on the ground that in the latter the evidence showed that the defendant did not intend "to inflict injury;" Bleiweiss v. State, 188 Ind. 184, 122 N. E. 577 (1919); State v. Miller, 292 Mo. 124, 234 S. W. 813. (1921); State v. Brown, 304 Mo. 78, 267 S. W. 871 (1924); State v. Fishwick, 33 Ohio Cir. Ct. 63 (1911); Commonwealth v. Bergdoll, $55 \mathrm{~Pa}$. Super. 186 (1913); Commonwealth v. Gayton, $69 \mathrm{~Pa}$. Super. 513 (1918); Commonwealth v. Coccodralli, $74 \mathrm{~Pa}$. Super. 324 (1920). See also Note (1915) 13 Mich. L. Rev. 594; (1919) 17 Mich. L. Rev. 705; Note (1924) 22 Mich. L. Rev. 717 (dealing with compulsory automobile insurance); (1915) 63 U. PA. L. REv. 803; (1916) 2 Va. L. Rev. 621; Note (1923) 1 N. C. L. REv. 235.

If death results, the defendant is guilty of manslaughter. See cases collected in 41 A. L. R. 725 (1926) annotation; 42 A. L. R. 1120 (1926) annotation; (1915) 63 U. PA. L. REv. 320. See for an extreme case, Keller v. State, 299 S. W. 803, 804 (Tenn. 1927) where the court said: “. . . . we think the policy of the law forbids an investigation as to probable consequences when the driver of an automobile under the influence of an intoxicant ... runs his car over another person and kills him on the public highway of the state." See Note (1928) 41 Harv. L. REv. 669. See also BABBITT, AUTOMOBMES (Blakemore's ed. 1923) § 1991. 
or neither of the defendants should be held to have intended the injury. But such is not the result. In the second case the defendant is guilty because he "intended" to inflict the injury, while in the third case he is innocent bccause he did not have this "intent." ${ }^{20}$ If intent means anything in these cases it is merely a two-syllabled method of expressing conveniently a set of operative facts. Defendant, then, in case two is held guilty on the unexpressed assumption that such conduct is more dangerous to society than the conduct of the defendant in case three, and that, consequently, more benefit is to be derived by punishing the former defendant than the latter.

Viewing these cases in a legalistic way again one wonders what has become of the traditional distinction between "intentional" and "non-intentional " conduct..2 "Intent to inflictinjury" seems, when analyzed, to be a hybrid product formed by combining intent to step on the accelerator and "reasonable anticipation of natural and probable consequences." Obviously the conduct characterized is classic negligence clothed in the familiai outer garments of intent. The disguise is achieved by the simple process of going back far enough in the chain of causation to reach a certain type of conduct which can plausibly be termed intentional. Then by combining this with the abstiaction of natural and probable consequences the result is obtained. As a pure problem of dialectics, no obstacle presents itself to prevent the courts in this manner from abolishing almost completely the distinction between "intentional" and "non-intentional" conduct. The only possible exceptions of any importance are the cases of pure omission or forgetfulness. The law would probably find it difficult to single out an "act" of the defendant in the chain, which could be said to have been intended.?n But the reasons

${ }^{20}$ State v. Albartelli, 112 Atl. 724 (N. J. L. 1915); State v. Rawlings, 191 N. C. 265,131 S. E. 632 (1926) ; see Luther v. State, supre note 19, at 625, 98 N. E. at 643; Radley v. State, 197 Ind. 200, 203, 150 N. E. 97, 93 (1925); State v. Schutte, 88 N. J. L. 396, 96 Atl. 659 (1916); (1910) 17 MIICE. L. REv. 705; (1915) 63 U. PA. L. REv. 805; (1924) 22 MIICr. L. Rev. 717. But see State v. Fishwick, supra note 19.

Tex. Penal Code (1920) art. 1022a provides: "If any driver or operator of a motor vehicle or motorcycle ..... shall wilfully or with gross negligence, collide with or cause injury to any other person .... he shall be held guilty of aggravated assault." An information in a prosecution under this statute will not be upheld, but it states that defendant drove "carlessly and negligently." Tarver v. State, 83 Tex. Cr. 275, 202 S. W. 781 (1013). And a conviction will be reversed if the jury is instructed that they may convict if they find that defendant drove in excess of the statutory limit. Wright v. State, 90 Tex. Cr. 435, 235 S. W. 886 (1921).

21 "It seems obvious that under the beneficient fiction of implicd intent, we are developing a doctrine of negligent assault and battery ...." (1919) 17 IIICH. I. REv. 705,

22 Such a situation would, of course, not present an insuperable obstacle to a determined court. A Watsonian behaviorist would not have any 
for acquitting the man who omitted to do a certain thing and convicting the one who did something do not seem apparent.

Suppose, that in case two, the state, instead of indicting the defendant under the simple assault and battery statute, charged him with assault with a deadly weapon with intent to inflict injury. ${ }^{23}$ In the former case it will be remembered that the courts admit the necessity of finding intent to inflict injury and proceed to find it. In other words the requirement "intent to inflict injury" is self-imposed by the court. In a prosecution under the latter statute the same requirement (at least the same language) is imposed on the court by the legislature. One would expect that this difference in the source of the requirement would not be regarded as material. Generally, however, the difference is vital, for where the defendant in case two is charged with assault with intent to inflict serious bodily injury he is acquitted. ${ }^{24}$ The ground given ${ }^{25}$ is that here a "specific" intent is necessary.26 But why, since the identical language is used in both cases is "ordinary" intent necessary in one case and "specific" intent in the other? Resort to legal analogy, logic or dialectics merely increases the bewilderment. The problem will remain unsolved as long as it is attacked from the traditionally conceptual angle.

difficulty. To him all conduct is explained in terms of stimulus and response. The mere fact that in one case the defendant stepped on the accelerator and in the other forgot to turn on his lights or to have his brakes relined, would be of no importance. See WATSON, Benaviomism (1927).

${ }^{23}$ E. g., State v. Richardson, 179 Iowa 770,162 N. W. 28 (1917).

24 People v. Hopper, 69 Colo. 124, 169 Pac. 152 (1917); State v. Richardson, supra note 23; Shorter v. State, 147 Tenn. 355, 247 S. W. 985 (1923); cf. Coffey v. State, 82 Tex. Cr. 481, 200 S. W. 384 (1918). Contra: Chambliss v. State, supra note 7; People v. Clink, 216 Ill. App. 357 (1020); People v. Benson, 321 Ill. 605, 152 N. E. 514 (1926); State v. Sudderth, 184 N. C. 753,114 S. E. 828 (1922). But see infra p. 1068.

25 "We may assume, for the purposes of argument, that the legislature could declare that if any injury short of death be inflicted through the reckless operation of an automobile, or failure to carry a light, that, without reference to intent, it shall constitute the crime of assault with intent, it shall constitute the crime of assault with intent to inflict great bodily injury upon the one who was injured. It has not yet so declared. We may so assume the legislature could enact a statute prescribing a punishment greater than that for reckless driving if such injure one upon a highway. There is, as yet, no statute." State v. Richardson, supra note 23, at 777, $162 \mathrm{~N}$. W. at 30 .

${ }^{26}$ Probably the cases meriting the most severe punishment are those of injuries caused by an intoxicated driver. The pitfalls of the purely syllogistic process of arriving at results is well illustrated by the following: Intoxication is a defense where the crime requires a specific intent. State v. Whitten, 115 Ala. 72, 22 So. 483 (1897). This intoxicated driver is charged with assault with the specific intent to inflict serious bodily injury. He could not have had the requisite specific intent and is therefore not guilty! 


\section{CONSEQUENTIAL ASPECT OF THE PROELEM}

As soon as the automobile came into common use statutes were enacted in the various states forbidding with more or less degree of particularity "reckless" driving and providing small fines for violation. But with the tremendous increase in the use of automobiles the violations became more frequent and the dangers to people on the highways greater. Faced with the realization that the ordinary reckless driving statute was not very effective as a deterrent, the courts, believing that an increase in penalty would in a measure decrease the evil, began to convict under the assault and battery statutes, simply because the penalty in the latter case was more severe. ${ }^{27}$ Thus, a reckless driver, luchy enough to escape injuring someone will, if he gets caught, suffer a small fine; but another, who injures a person while driving in exactly the same way, is more likely both to get caught and suffer a more severe penalty. In both cases the conduct of the defendant is the same. Aside from the fact that in the case of assault and battery someone is injured, the sum total of the difference in the two crimes is to be found in the penalties. The courts having taken it upon themselves to weigh the efficiency of the penalties ascribed by the legislatures for reckless driving, have come to the conclusion that they are not efficient, and, acting on the assumption that a more severe penalty will act as a greater deterrent, have increased the penalty by the simple process of squeezing the case into the most easily accessible category-assault and battery. Although the machinery creaks and groans, the courts are stoical in their insistence that the extra burden be carried. Policy so demands.

The fact that the majority of courts acquit when the defendant is charged with assault with intent to kill, can obviously not be explained satisfactorily by contending that the telm "intent" suddenly suffered a chameleonic change when used by the legislature. If, however, attention is focused on the eventual results instead of on the "inherent" meaning of concepts, a decently plausible reason for the distinction appears. Why is it not reasonable to assume that whereas the courts are willing, let us say, to go so far as sentencing a man to pay a fifty dollar fine, they do not think it advisable to inflict a jail sentence of six months? ${ }^{28}$

In State $v$. Richardson, ${ }^{29}$ an Iowa decision of 1917, the defendant was driving a car, which "as to brakes and other equipment, was in such a condition as to interfere with efficient control, and perhaps power to stop." In violation of statute the defendant drove his car without lights during a dust storm. The jury

27 See infra notes 55-112.

28 See, for example, the statutes of California, infra notes 59-63.

23 Supra note 23. 
could find that he was driving at a speed prohibited by statute and, at any rate, at a speed that it was under the circumstances negligent to indulge in. The defendant's car struck the prosecuting witness's while the latter was sitting at the side of the road repairing a tire. The indictment charged the defendant with "assault with intent to inflict great bodily harm." The court instructed the jury, inter alia, as follows:

"Careless driving of an automobile and reckless indifference to the life and safety of others, if shown by the evidence may supply the criminal intent required. If one by careless and reckless driving of an automobile unintentionally run over or strike another and inflict upon him a great bodily injury such act will constitute assault with intent to do him great bodily injury." 30

The jury returned a verdict of guilty under the indictment. The conviction was reversed on the ground that under the facts the specific intent necessary for conviction could not be found. The court said, "The difference between assault and assault with intent to inflict a great bodily injury is the specific intent to inflict an aggravated injury." 31 It then proceeded to discuss various cases in which the concept specific intent had been examined, and then concluded, "The conviction cannot stand. This does not exclude a conviction for assault and battery or assault."

In People v. Hopper, ${ }^{32}$ a Colorado case also decided in 1917, the defendant while driving in a much travelled part of the city at 45 or 50 miles an hour, struck a car in which the prosecuting witness was driving. The indictment charged that the defendant "with a deadly weapon, . . . an automobile, did make an assault on one Frank W. Beard with intent . . . . wilfully and maliciously to commit a bodily injury upon the person of the said Frank W. Beard. . . ." The lower court directed a verdict of not guilty and the state appealed. It was held that the direction of a verdict of not guilty of the assault with intent was proper because "there was, according to the evidence, no specific intent on the part of the defendant "to commit a bodily injury upon the body of the said Frank W. Beard.'" s3 There was, however, evidence upon which to base a conviction for simple assault and the jury should have been instructed accordingly.

In Iowa reckless driving is punishable by fine not exceeding $\$ 100$, or by imprisonment for not more than 30 days. $^{34}$ Assault

\footnotetext{
${ }^{30}$ Ibid. $775,776,162$ N. W. at 30.

31 Ibid. $785,162 \mathrm{~N}$. W. at 33 .

3269 Colo. 124, 169 Pac. 152 (1917).

${ }^{33}$ Ibid. at 125, 126, 169 Pac. at 153.

34 Code of Iowa (1927) § 5089. Secs. 5030, 5030-b1 authorize cities and
} 
and battery is punishable in the same way. ${ }^{35}$ Assault with intent to inflict great bodily injury is punishable by imprisonment in the penitentiary or county jail for not more than one year, or by a fine of not more than $\$ 500.50$ In Colorado, reckless driving is punishable by fine of not more than $\$ 300$ or by imprisonment in the county jail for not more than 30 days, or by both. ${ }^{37}$ Assault and battery is punishable by fine of not more than $\$ 100$ or by imprisonment in the county jail for not more than six months. ${ }^{3 s}$ Assault with a deadly weapon with intent to inflict a bodily injury is punishable by a fine of not more than $\$ 2,000$ or by imprisonment in the county jail for not more than one year..$^{39}$

Superficially, these cases seem to present no more profound operation than that of the formulation of minor premises to fit into a preconceived major premise. Every assault and battery requires an intent to inflict injury. This defendant did or did not intend to inflict injury. Therefore he is or is not guilty of assault and battery. Or, every assault with intent to inflict injury requires a specific intent. This defendant did or did not specifically intend to inflict injury. Therefore, he is or is not guilty of assault with intent to inflict injury. It is not the purpose of this article to inquire into the meaning or utility of this major premise, but rather to point out that there is a delusive appearance of an immaculate conception of the minor premise and to inquire into the materials used in its creation. It is submitted that, because of its various connotations, the term "intent" has lost such a great part of what once may have been descriptive properties, that the operation of arriving at a result is no more than a process of pure logic, which hides from view problems of penal policy which should be squarely faced by the courts. A defendant injures someone while driving "recklessly." It is possible to make major or minor premises of the proper stuff to get a conviction for reckless driving, assault and battery, or assault with intent to inflict injury. But premises are not self-creative. A choice must be made. When a court decides that a reckless driver intended to inflict injury and is therefore guilty of assault and battery which carries with it a penalty

towns to pass speed ordinances and to fix punishments not to exceed $\$ 25$ or 5 days in jail.

35 Ibid. § 12929.

36 Ibid. \$ 12934.

37 Colo. Comp. Laws (1921) \$1273.

38 Ibid. § 6699.

39 Ibid. \$ 6698 . 
of six months in jail, when it could have found him guilty of violating a simple reckless driving statute or ordinance, it is in fact saying:

"In our opinion, drivers of automobiles, as a class, will react in accordance with the severity of the punishment. The legislature has specifically provided a penalty to cover cases like this which, in our opinion is not severe enough. There are altogether too many accidents caused by reckless driving. Increase of the penalty to 6 months will have its effect on decreasing the number of accidents. Therefore, the defendant is guilty of assault and battery."

Such a process of arriving at results is more intelligent than the one of seemingly doing nothing but finding that the defendant "intended" to inflict the injury and is, therefore, guilty of assault and battery.

It may well be that by convicting for assault and battery instead of reckless driving a more desirable result is reached, but it is quite probable that the fact that the courts obscure from view the penological aspect of the problem tends to perpetuate the too long existing compartmental division of criminology from the law. In this connection it may be worthwhile to examine any recent case dealing with this problem for the purpose of showing how authorities are cited merely because they happen to contain an apt formula concerning intent. In the leading case of State $v$. Shutte ${ }^{40}$ the defendant drove his automobile through a city street at a rate of speed in excess of that permitted by statute and ran into a pedestrian. He was convicted of assault and battery. On appeal, the court first stated that counsel for defendant was correct in contending that "both the wilful wrongdoing that constitutes malice in the law and also an intention to inflict injury are of the essence of a criminal assault; ${ }^{41}$ and that as a necessary corollary mere negligence will not sustain a conviction for such crime." It then went on to point out that "intent" may by inferred in law from the consequences that are naturally to be apprehended as the result of the particular act, the doing of which was intentional. ${ }^{42}$ The following language from The Queen $v$. Martin was quoted:

"The prisoner must be taken to have intended the natural consequences of that which he did. He acted unlawfully and maliciously, not that he had any personal malice against the particular individual injured, but in the sense of doing an act

40 Supra note 18.

41 Ibid. 16, 93 Atl. at 113.

42 Ibid. 
calculated to injure, and by which others were, in fact injured." 43

In that case the defendant, just prior to the close of a theatre performance, had turned out the lights and locked the doors. A panic followed and several people were severely injured. The indictment charged "that he did unlawfully and maliciously inflict grievous bodily harm upon. . . . . He was held guilty.

The next case cited was People v. Morehouse." There the defendant pointed a gun at the prosecuting witness in a threatening manner. Counsel for defendant requested the court to instruct the jury that if the gun was unloaded the defendant was not guilty. The request was refused and on appeal the ruling was affirmed.

In Smith v. Commonwealth the defendant "in fun" discharged a pistol in a railroad train, the bullet entering the leg of one of the passengers. He was indicted under two counts, simple and aggravated assault, and found guilty under both. The conviction was affirmed, the court saying:

"In a case somewhat analogous in principle to the one before us, it was said in reference to the prisoner: 'He acted unlawfully and maliciously; not that he had any personal malice against the individuals injured, but in the sense of doing an unlawful act calculated to injure, and by which others were, in fact, injured. Just as in the case of a man who fires a gun among a crowd, it is murder if one of the crowd be thereby killed.' Queen v. MTartin." 45

In People v. Raher, ${ }^{47}$ the next case cited, the defendant who had fired a revolver at a crowd of people resulting in injury to the prosecuting witness was found guilty of assault with intent to do great bodily harm. The judgment was affirmed on the ground that it was unnecessary to prove that the defendant intended particularly to injure the prosecuting witness.

The reported opinion of State v. MIyers, ${ }^{48}$ the next case cited, fails to disclose what the facts were except that the defendant was the confederate of some one who shot the prosecuting wit-

\footnotetext{
438 Q. B. D. 54,58 (1881).

4453 Hun 638, 6 N. Y. Supp. 763 (1889).

$45100 \mathrm{~Pa} .324$ (1882).

46 Ibid. 329, 330.

4792 Mich. 165, 52 N. W. 625 (1892).

4319 Iowa 517 (1865).
} 
ness. The defendant was convicted and appealed, claiming as error the fact that the court erred in instructing the jury that:

"if two or more persons combine to do an unlawful act, the declarations and acts of each, made and done with reference to the common purpose, implicate alike all, and each in law is guilty and may be punished for the offense as a principal."

The instruction was upheld. The court, in the cited case, then went on to add, "An assault may be committed without doing any personal injury. Recklessly shooting into a crowd, and wounding someone, not intended, is criminal."

In Com. v. Hawkins the defendant was charged with an assault with a deadly weapon. The defendant had been annoyed by different people ringing his door bell and insulting him when he came to the door. The defendant, who was under the influence of liquor, finally fired a revolver and a bullet struck the prosecutrix who was some 200 feet away. The lower court instructed the jury that it was not necessary in order to hold the defendant guilty to find that he intended to hit the prosecutrix. The jury returned a verdict of guilty. On appeal, this was affirmed, the court saying:

"There has been much discussion in the cases in regard to the nature of the intent necessary to constitute this crime, but the better opinion is that nothing more is required than an intentional doing of an act which, by reason of its wanton or grossly negligent character, exposes another to personal injury, and causes such an injury." ${ }^{40}$

The court in State $v$. Shutte, after merely citing these authorities seemingly to bear out its contention that the intent necessary to convict for assault and battery was present, then stated that counsel for defendant contended that a mere act of negligence would not sustain a conviction for assault and battery. For this proposition counsel cited State $v$. Thomas, ${ }^{50}$ which, in commenting on State v. O'Brien,"si said, "Certainly if death had not ensued from his negligence, but only personal injury, a charge of criminal assault and battery could not have been sustained." 52 The court in State v. Shutte then agreed with the proposition that mere negligence would not sustain a conviction for assault and battery and said:

"On the contrary, we are dealing with a wilful act done under circumstances that rendered likely the infliction of such an in-

\footnotetext{
49157 Mass. 551, 554, 32 N. E. 862, 863 (1893).

5065 N. J. L. 598, 48 Atl. 1007 (1901).

5132 N. J. L. 169 (1867).

'2 Supra note 50, at 600, 48 Atl. at 1008.
} 
jury as that which actually resulted from it. ... . The running of a car at a high rate of speed is an act in which the will of the driver concurs, and hence is clearly a wilful act as distinguished from merely negligent conduct, when considered with respect to the state of mind of the offender; which is what the criminal law considers." 53

It is thus seen that not a single one of the authorities cited has any resemblance to the problem of determining whether the penalty fixed by the legislature for reckless driving should be increased by holding the defendant guilty of assault and baltery. It is true that prior to this case the New Jersey courts had not passed on the point, but even so, how can cases dealing with the problem of what should be done with a defendant who caused a panic in a theatre by turning out lights and locking doors, shed any light on the problem of determining what should be done with one who injures a person while driving recklessly? The seeming similarity could not possibly exist if it were not for the habit of courts to examine language used in other cases and apply it to the problem considered without paying the slightest attention to the purpose for which it was originally used.

A lawyer would probably describe the cases here under consideration by saying that the defendants are generally held guilty of assault and battery, but not of assault with the specific intent to injure or kill. He would then cite as contra to the last statement, the states of Illinois, Georgia and North Carolina. In these three states reckless drivers causing injury may be convicted of assault with a dangerous weapon with intent to cause serious bodily injury. It is submitted, however, that this bird's eye view of the decisions gives a picture of only delusive symmetry. An examination of the statutes of the states which have passed on the problem reveals a chaotic condition of the penal consequences that may be inflicted for very similar conduct. New Jersey and Tennessee are in accord only in so far as there is identity in the name of the crime. The following table shows how widely the penalties differ. The column "driving while intoxicated" is included since in some of the cases the defendant could have been convicted under that statute.5t

\footnotetext{
5s Supra note 18, at 18, 93 Atl. at 114.

54 The heading "aggravated assault" is used merely for convenience as there are many variances in the terminology used in the different statutes.
} 
Arizona

Californla

Colorado

Gocrgla

Ilitnols

Indlana

Iowa

missourl

$\mid$\begin{tabular}{l}
\multicolumn{1}{c}{$\begin{array}{c}\text { Reckless } \\
\text { Driring }\end{array}$} \\
First Offense: $\$ 10-\$ 100$. \\
Second Offense: $\$ 50-\$ 300$. \\
Third Ofrense: Suspen- \\
sion of license for one \\
sear. (55)
\end{tabular}

First Offense: Not moro than $\$ 50$ fine or imprisonment in county jain Second Offense: Not moro than $\$ 1$ co fine or impris onment in county jail for no more than 10 days or noth

Third Offense: Not more than 500 fine or impris onment in county jail fo no more than 6 mos., or both. (59)

Fine of not more than $\$ 300$ or imprisonment in county jail for not more than Jodays or both. (O

Mrisdemeanor punishable by fine of not more than 1.000 or jmprisonment mor more than chain fanc for not more than 1 ans bination of these. (68)

$\$ 10-\$ 100 .(71)$

First Offense: Mrarimum ine of $\$ 100$ Second Ofiense: Mraxi mum fine of $\$ 1.000$, to which may be added 10 dass to 6 mos. imprisonment. (75)

Maximum fine of $\$ 100$ or imprisonment for not

Fine of $\$ 25-\$ 100 .(82)$

Drixing While
Intosicated
First Offense: 30 -90 days
in the county jail.
Second offense: 6 mos.
in county jail and sus-
pension of operator's li-
cense for one year. ( 56$)$
Imprisonment in county

jail 00 dass 1 year, or jn State prison 1-3 yrs. or If intoxication is canso of injuries fine of no more than $\$ 500$, or State prison for no more than

Death caused by rcekless runken ariver is a $\mathrm{fel}$ ony and punishable bs penitentiary for 1-14 yrs. if injury so ca

(

Fine of not more than $\$ 200$ or/and imprison ment in county jail for

First Oficnse: 3raximum fine of \$500 to which onment in the county inil or state the counts

dass to 6 mos. ony $1-5$ yrs. and $A$ lel pririlece to drive for 1 yr. (76)

Imprisonment in State penitentiary for jot more than 1 yr.. or fine of not more than $\$ 1,000$. or both. (79)

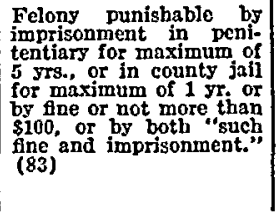
Sanio

Simple Ascult and Hattery

Not more than $\$(G i l 0$, or in the county fall. (57)

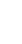

Fine or not moro than in or imprisonencut in county iall for 0 mos or both. (c2)

County jail for not more than 6 mos. or fine of not more than $\$ 100$. (60)

$$
\text { . }
$$

$\$ 3-\$ 100 .(73)$

Fine not moro than s1fon to which may bo added counts jail not exceding 6 mos. (77)

Imprisomment for not more than 3 days, or (80)

Maximum fino of $\$ 100$ or maximum imprisonment in county jall for 6 mos. or both. (81)
Fine of not taore than $\$ 2.10$ (if and linturisonentent in tlo county fill Ior tot inora than 1 yr. (67)

No statuto ot neterarated assault, but asstult sith Intent to mitrder "loy using any wetupon llkoly $_{\text {to }}$ to prolite by dimprison punishable by tmprison. ment and fator in pent(7i)

$\$ 25-\$ 1$, 000 , or ltaprlson. ment in tho county jal for not more than $1 \mathrm{yr}$. or botli. (74)

Imprisoniacut In count Jall for not moro than 1 yr. or masintutn flud of penitentinery for maxt inum of 1 yr. (81)

Imprisoninent In penis tentlary for maximuti of 6 grs. or In county Jal for not less than o mos. or by a flite of not less than \$100 and inforisons ment in the coutily jal for not less thine a mos. or by fillo of tot les 


\begin{tabular}{|c|c|c|c|c|}
\hline & $\begin{array}{l}\text { Reakless } \\
\text { Drifins }\end{array}$ & $\begin{array}{l}\text { Diving While } \\
\text { Intoricated }\end{array}$ & Sign' a Arezult & 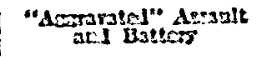 \\
\hline New Jersey & Fine of $\$ 100 .(83)$ & 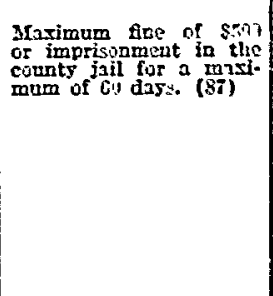 & 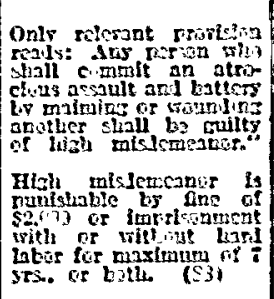 & 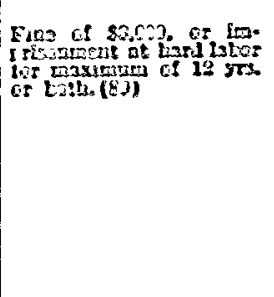 \\
\hline Nozth Carolina & $\begin{array}{l}\text { 3rarimum fine of } \$ 5 n \text {. or } \\
\text { imprisonment for } \mathrm{maxi} \\
\text { mum of } 33 \text { dass. }(90)\end{array}$ & 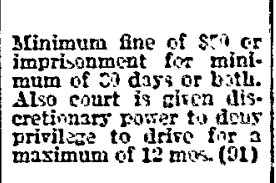 & 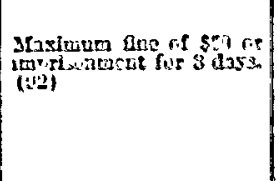 & 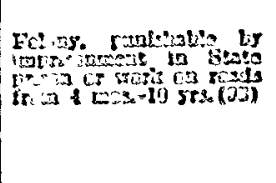 \\
\hline Ohio & 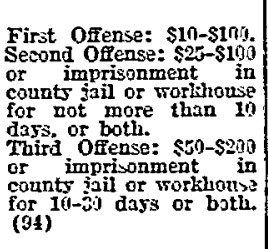 & 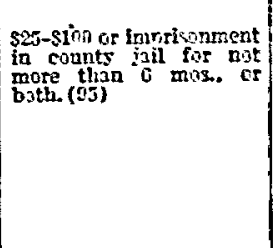 & 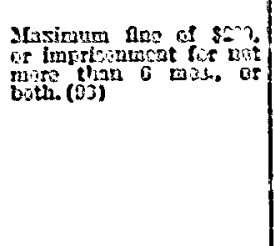 & 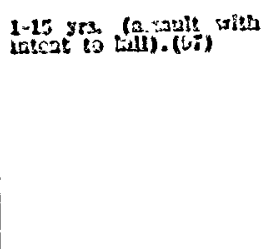 \\
\hline Pennsylvania & $\$ 10-\$ 25$ fine. (98) & $\begin{array}{l}\$ 100-5 m \text { or imp-isun. } \\
\text { ment for } 1 \text { sr. or both. } \\
\text { (\$3) }\end{array}$ & 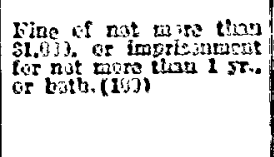 & 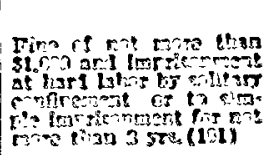 \\
\hline Tonnesseo & Fine of $\$ 5-\$ 50$. (102) & 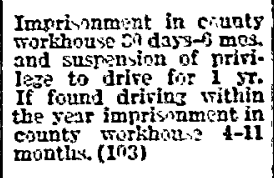 & $\begin{array}{l}\text { Seamingls no penalty } \\
\text { Ared for assult art } \\
\text { battery. }\end{array}$ & 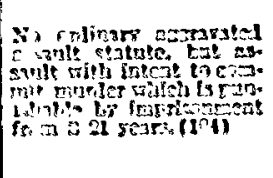 \\
\hline Texas & Fine of $\$ 5-\$ 230 .(100)$ & 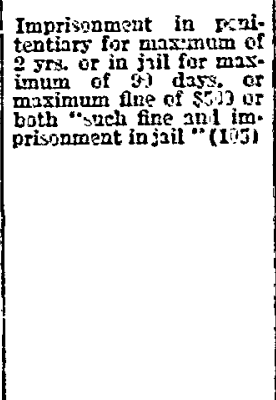 & Fine of $55-5=3 .(103)$ & 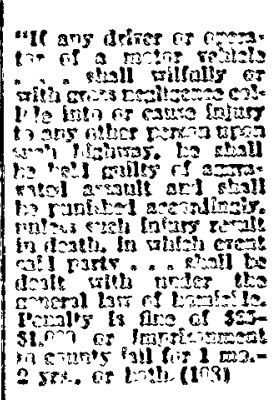 \\
\hline Wisconsin & 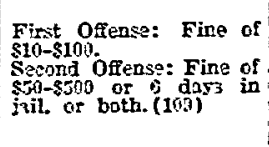 & 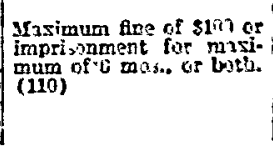 & 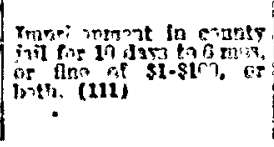 & 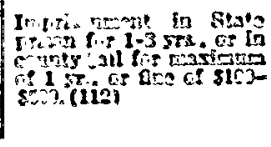 \\
\hline
\end{tabular}


It will be noted that the penalty for "aggravated assault" is generally more severe than that for simple assault and battery, and the penalty for the latter is more severe than that for reckless driving. In Georgia, however, the penalties for assault and battery and reckless driving are the same and there is no "aggravated assault" statute. Since it would obviously have been pointless to have tried the defendant for simple assault and

${ }^{55}$ Ariz. Laws (1922) c. $27, \S 6$.

${ }^{56}$ Ariz. Laws (1923) c. 28, §§ 1, 2.

57 Ariz. Rev. Stat. (1913) $\$ 210$.

58 Ibid. \& 219: "assault upon the person of another with a deadly werpon ... or by any means or force likely to produce great bodily injury ..." A simple assault resulting in serious injury is an aggravated assault. Ibid. $\S \S 215(5), 217$. It was under the latter statute that the defendant in Brimhall v. State, supra note 19, was prosecuted.

${ }^{59}$ Cal. Gen. Laws (Deering, 1923) Act 5128, § 153.

60 Ibid. § 112.

6x Cal. Penal Code (1923) \& 367e.

62 Ibid. § 243.

63 Ibid. § 245.

64 Supra note 37.

os Colo. Laws (1923) c. 95, §§ 1, 2.

66 Supra note 37, \& 6699.

${ }^{67}$ Ibid. \& 6698; "assault with a deadly weapon ... . with an intent to commit . . . a bodily injury . . . "

Gs Ga. Laws (1927) § 11, 26; Ga. Penal Code (1926) § 1065.

$69 \mathrm{Ga}$. Penal Code (1926) §§ 102, 1065.

${ }^{70} \mathrm{Ibid}$. § 97. There is no "aggravated assault" statute similar to those in other states.

${ }^{11}$ Ill. Rev. Stat. (Cahill, 1927) c. 95a, § 12.

72 Ibid. \& 42.

${ }^{73}$ Ibid. c. $38, \S 34$.

74 Ibid. c. 38, § 37: "assault with a deadly weapon ... with an intent to inflict . . . a bodily injury."

${ }^{75}$ Ind. Acts (1927) c. $230, \S \S 2,3$.

${ }^{76}$ Ann. Ind. Stat. (Burns, 1926) $§ 2725$.

77 Ibid. § 2419.

78 Supra note 34.

${ }^{79}$ Supra note $34, \S 5027$.

80 Supra note 35.

${ }^{81}$ Supra note 36. Sec. 5091 provides that a conviction for violation of any of the provisions of the motor vehicle act is no bar to a prosecution for "an assault committed by any person in operating motor vehicles."

82 Mo. Rev. Stat. (1919) c. 71, § 7601.

${ }^{83}$ Mo. Rev. Stat. (Ann. Supp. 1927) c. 71, § 29 (c). This amended Mo. Rev. Stat. (1919) c. $71, \S 7601$ which provided the same punishment as for reckless driving.

84 Mo. Rev. Stat. (1919) § 3265.

85 Ibid. § 3262. See also $\$ 7601$.

${ }^{86}$ N. J. Comp. Stat. (1911) 3441, § 35.

87 Ibid. .

88 Ibid. 1782, § 113; 1812, § 217.

89 Ibid. 1782, § 113.

${ }^{90} 1$ N. C. Consol. Stat. (1919) § 2599. 
battery, in Chombliss v. State, ${ }^{113}$ a recent Georgia case, he was tried and convicted for assault with intent to murder (2-10 years), since that was the only decently plausible crime the penalty for which was more severe than that for reckless driving. On appeal, counsel for defendant contended that the defendant was not guilty of the crime charged since no "malice" had been shown. The conviction was affirmed, the court saying:

"There was ample evidence to authorize the jury to find that the defendant, while under the influence of intoxicating liquor, was driving his car at an unlawful rate of speed, in a recliless manner and with utter disregard for the lives and safety of others." 214

\footnotetext{
91 Ibid. $\$ 4506$.

92 "In all cases of an assault, with or without intent to kill or injure, the person convicted shall be punished by fine or imprisonment, or both, at the discretion of the court: Provided, that where no deadly weapon has been used and no serious damages done, the punishment in assaults, assault and battery, and affrays shall not exceed a fine of $\$ 50$ or imprisonment for 30 days; but this proviso shall not apply to cases of assault with intent to kill or with intent to commit rape, or to cases of assault or assault and battery by any man or boy over 18 years old on any female person." Ibid. $\$ 4215$. Query as to the result if a reclless male driver over 18 injured a female.

${ }_{93}$ Ibid. \$ 4214.

94 Ohio Gen. Code (Page, 1926) 12603-2. And in case the defendant is found to have operated his car at more than a certain rate of speed, the court may commit him to the county jail or worlhouse for not more than 5 days in addition.

95 Ibid. \& 12628-1.

${ }^{96}$ Ibid. $\$ 12423$.

9ז Ibid. \$ 12421 .

98 $\mathrm{Pa}$. Digest (Purdon, 1916) §5320.

99 Ibid. § 5318.

100 Ibid. 307 , par. 34.

101 Ibid. par. 35: "unlawfully and maliciously inflict . . . with or without any weapon . . . any grievous bodily harm."

102 Tenn. Code (Thompson's Shannon, Supp. 1926) $\$ 30790-195$, reducing former penalty of $\$ 25-\$ 100$. See Tenn. Code (Thompson's Shannon, 1018) § 3079a-12a-1. ${ }_{103}$ Tenn. Code (Thompson's Shannon, 1926) $\$ 6495-25, \mathrm{b1}$. $10 \leq$ Ibid. $\S 6467$.

105 Tex. Rev. Crim. Stat. (1925) art. 790. The previous penalty was a maximum fine of $\$ 100$. Tex. Penal Code (1920) art. s20yy.

${ }^{106}$ Ibid. art 802.

107 Tex. Pen. Code (1920) art. 1022. The punishment for ordinary statutory "aggravated assault" is a fine of \$25-1000. Ibid. art 1024.

108 Ibid. art. $1022 a$.

109 Wis. Stat. (1927) § 85.22.

110 Ibid. § 343.182.

111 Ibid. § 340.57 .

112 Ibid. $\$ 340.41$ : "assault . . . with intent to do great bodily harm." 113 Supra note 7.

134 Ibid. 80.
} 
Is this case authority for the proposition that a drunken, reckless driver who seriously injures another is guilty of assault with intent to murder?

In lllinois the penalty for reckless driving is a fine of $\$ 3-\$ 100$ and that for simple assault and battery is $\$ 25-\$ 100$. The penalty for "assault with a deadly weapon . . . with an intent to inflict . . . a bodily injury, where no considerable provocation appears, or where the circumstances of the assault show an abandoned and malignant heart" is a fine of $\$ 25-\$ 1,000$, or imprisonment in the county jail for a period not exceeding one year or both. Since, again, it would have been pointless to have convicted the defendant of simple assault and battery, in People $v$. Benson ${ }^{115}$ it was found that an automobile was a "deadly weapon" and after careful anatomical observation, that the defendant's heart was abandoned and malignant and that he "intended to inflict a bodily injury."

In North Carolina simple assault and battery and reckless driving are both punishable by a maximum fine of $\$ 50$ or imprisonment for a maximum of 30 days. One who "assaults another with a deadly weapon or with intent to kill, and inflicts serious injury" is guilty of a felony and subject to imprisonment in state's prison or to work on the county roads for a period not less than 4 months nor more than 10 years. Just as in the previous two cases, nothing would be accomplished if the defendant was convicted of assault and battery; a conviction of assault with a deadly weapon with intent to kill was upheld in State v. Sudderth.116

These are the only states ${ }^{117}$ in which reckless drivers causing injury have been convicted of some form of "aggravated assault." If no attention is paid to the scales of penalties in these states it is quite possible that when the problem arises in a neighboring state which has not yet passed on the question, these cases will be followed even though the necessity for such a penalty does not exist. It is more than a striking coincidence that, of the states which have passed on the problem, these are practically the only three in which assault and battery is not more severely punishable than reckless driving. ${ }^{118}$ The reason

\footnotetext{
${ }^{115}$ Supra note 24. See People v. Clink, supra note 24. But of. People v. Anderson, 310 Ill. 389, 141 N. E. 727 (1923).

${ }_{116}$ Supra note 7.

117 In Brimhall v. State, supra note 19, the defendant was convicted of "aggravated assault" but in Arizona, aggravated assault is defined in the same way as simple assault plus serious injury.

118 The only seeming exception is Iowa where there is no difference between the penalties for reckless driving and assault and battery. The Iowa Supreme Court refused to sustain a conviction for assault with intent to inflict bodily injury. State v. Richardson, supra note 23. This
} 
why a reckless Georgian driver is held guilty of assault with intent to murder, is because it is the only available statutory pigeonhole which is more severe in its consequences than reckless driving or assault and battery.

It is not here contended that all the ills of the criminal law can be cured by the use in the decisions of the magic wand of emphasis on penalties. It is rather merely suggested that probably in no field of the law is the divorce from other branches of the social science more marked than in the criminal law. That breach can only be widened by the complete refusal of courts in criminal cases ever even to suggest openly the necessity of considering penalties in individual cases. It must be recognized that in cases such as those discussed here, the courts are really determining what penalties should be meted out to particular offenders. The function should be openly expressed.

means that the court regarded the penalty for recliless driving (maximum fine of $\$ 100$ or imprisonment not exceeding 30 days) as suficient. 